\title{
Social Impact of Foreign Labor Migration in Malaysia
}

\author{
${ }^{*}$ Erna Liza ${ }^{1}$ and Sri Mulyati Binti Setu ${ }^{2}$ \\ ${ }^{1)}$ Graduate Student of Geography Education, Universitas Negeri Padang, Indonesia \\ e-mail: ernaliza226@gmail.com \\ 2) Student of Geography, Malaya University, Malaysia \\ e-mail: Srimulyatti96@gmail.com
}

*Corresponding Author, Received: September 14, 2018, Revised: October 21, 2018, Accepted: December 05, 2018

\begin{abstract}
In economy perception, the phenomenon of foreign labour migration in Malaysia might cause a sociopsychological impact, in this case, a negative impact, on the labour's family left in the home country. Foreign labours in Malaysia, especially the male ones who are also the head of the family, have changed their family's life pattern. This change disturbs their lives and, in most cases, sometimes could lead to stress and family problems. Human migration is a phenomenon inseparable from the development process in Indonesia. It is found in many regions in Indonesia. Indonesia is an example of a country where the phenomenon of interzonal migration and international migration happens every time. One of the nearest countries where many Indonesian labours migrate is Malaysia.
\end{abstract}

Keywords: The Impact of Migration, Labor, Foreign

\section{Introduction}

Malaysia is a country of various, plural and heterogeneous cultures, religions and ethnicities and a British Commonwealth country. The four largest ethnic groups populating Malaysia are Malay, Chinese, India and Malaysia's (indigenous people of Malaysia). Migration is the movement of people from one place to another with various intentions such as settling temporarily or permanently crossing political/state border administrative/regional borders of a country. People have been migrating since the beginning of human history. They move from one settlement to another, from town to town, and from city to city. However, it is inaccurate to assume that today's migration is same as the one in the past.

In addition to solving employment issue in Indonesia and increasing the country's foreign exchange, the phenomenon of Indonesian labours in Malaysia especially could help to improve the labour's and their family's fate standard of living in the home country. The studies conducted by Mantra (1989) and Hugo (1995) which focused on the economy aspect of labour migration also suggested such benefits. On the other hand, the migration process causes contradictions and applies new practices involving aspects of politic, economy, demography, culture, social, psychology and national dignity. This complicity is experienced by migrants, migrants'family and society of source or target place. This has more or less influenced the success of their work abroad. Some studies conducted, including Indonesia, is mostly limited to certain perceptions and topics and are not linked with the consequences that might occur in society. The topic limitation is that there are few studies investigating the impacts of migration on home country society, especially the impacts on migrant's family's welfare, structure and function.

At the family level, namely household, the phenomenon of foreign labour migration in Malaysia has caused a change in the behaviour patterns of children and wife and family relation. It usually happens in 
households left by husbands (head of the family) working in Malaysia.wives as a head of the family are not able to earn a living to fulfil their family needs. In addition to the economic problem, they also have to suffer from the psychological burden of being a "widow" and their children's neglected education. This article is about a study on various socio-psychological implications or impacts of foreign labour migration in Malaysia on migrants' family in the home country.

\section{Method}

The method this research used a qualitative approach, which described the study social impacts of foreign labour migration in Malaysia. The research subjects were Malaysian society selected through snowball sampling technique. Data were collected through observation, interview and documentation (Hermon et al., 2008). Type of observation used was passive participation observation while the interview was a semi-structured interview, a deep interview that followed main questions to obtain desired information. Research instruments were observation sheet for observing social interactions in Malaysia and interview guidelines containing questions related to determining factors of educational quality in social geography learning. Collected data was then analyzed in accordance with the research purpose. The collected data is then analyzed according to the research objectives. Meanwhile, in this study, a technique is used to analyze the social impact of Malaysia Miles and Huberman's labour migration analysis technique (Miles et al, 1994) other data analysis such as the east Lombok government policy using AHIP and statistical analysis.

\section{Results and Discussion}

The method is research used a qualitative approach, on the impacts of migration is commonly inseparable from changes, both material and non-material, that occur. The material impact can be physically and directly observed but the non-material impact of a change is materially not measurable. However, the latter can be seen in a society reflecting in the changes of its social structure, socio-cultural norms and the ones caused by psychological pressure and others. Current studies on a similar topic are a focus on the impacts of migration on a society, for example, the emergence of social stratification and inequality. Various migration patterns, such as chain migration, returned migrants, migrant network, and the relationship between migrants and aspects of community life become a study material and indicate certain socio-cultural condition due to migration (Hermon, 2009; Hermon, 2010). Materially, the impact of migration is used to associate with migrant's remittance for the family at home and how it is used by them. The collected data is then analyzed according to the research objectives. Meanwhile, in this study a technique is used to analyze the social impact of Malaysia Miles and Huberman's labor migration analysis technique (Miles et al.,1994; Hermon, 2015) other data analysis such as government policy and raw data from state government of east Lombok using AHIP model and statistic analysis (Hermon, 2014; Hermon, 2016; Hermon 2017).

On the socio-psychological side, Indonesian labour migration in Malaysia is seen to be problematic compared to its positive impact on labour's self and family and society in general. The socio-psychological impacts illegal migrants. They get into trouble on the trip, at work, and even when they return to their home country. For example, The migrants from EastLombok is illegal. They and their family left for Malaysia independently or through Taikong (brokers). During the trip and work, they are often mistreated, beaten or kicked by brokers or police officers of Indonesia or Malaysia.

The positive impact of foreign labour migration in Malaysia is that migrants can earn a higher income than the ones in their country (Hermon et al., 2018). Moreover, they also can pay for their children's school fee in the hope their family's education will improve. The socio-economy condition in their home which is impossible to meet their needs encourages them to go to other places with better earnings so that they can fulfil their needs. In other words, there is a significant difference of efficacy value between source place and target place that can cause population migration. Human migration tends to be affected by one's various needs. Hence, since everyone is different the assessment of each individual's source place is different. Consequently, the decision-making process to move of each individual is not the same. The impossible-tofulfil-the-needs condition of socio-economy in one's hometown motivates them to migrate to other better places.

There are four factors that cause foreign labour migration. First, hometown-originated supporting factors such as low income, limited employment, and limited physical condition that make people migrating 
and working abroad in order to increase their earnings and get high-paid jobs. Appealing factors from the target country are high salary, many job opportunities and experience. Next one is inhibiting factors. The study found no inhibiting factors such as distance, charge, and family that detain them to migrate and work abroad. The last one is a personal factor. Personally, labour decides to migrate because they want to be independent and improve their family's future. The impact of TKI (Indonesian labours) migration to Malaysia could be positive or negative. Positively it can improve the labor'ssocio-economic status and family in society but negatively illegal migrants experience mistreatment from brokers and even police officers.

\section{Positive Impact}

The impact of Indonesian labour migration on migrant's family economy is very positive. It improves the family economy. It is seen from the improvement of family income and prosperity in the home country. They use the money to fulfil their needs such as daily needs, cost of education of their children, and house or venture capital. The impact can also be noticed from their ownership of, for example, motorcycle, a nice house which is occupied by furniture, electronic equipment like television, washing machine, sewing machine, cooking utensils and others. Moreover, their family education is better. Before the migration, they did not think about their children education but after being TKI many of their children have become scholars.

\section{Negative Impact}

TKI who work in a very distant country can cause a negative socio-psychological impact on society. The family relationship becomes less harmonious. Poor financial management of family often forces TKI to repeatedly migrate to other countries. Millions of rupiah quickly disappear due to consumptive behaviour of children, wife or husband in the house. Another impact is the lack of supervision of child development and education. Sometimes when one of a couple works as TKI, there is a possibility of infidelity that will cause disharmony in the family. This happens when the bigger remittance the migrants send the higher their family's socio-economic status is. It can be seen from the number of agricultural lands they have, the number of household expenses, nice house and complete household facilities. This improvement then is not only able to better family prosperity but also able to improve rural development.

\section{Conclusion}

Migration is the movement of people from one country to another. Labor's migration happens for four reasons. They are home-originated supporting factors, personal factors, appealing factors of other countries, and inhibiting factors. The most common ones are related to home-originated supporting factors such as low income, limited employment, limited physical condition, and high-paid jobs in other countries. These are usually motivated by the economic condition in labour's home country, in this case, Indonesia, so they decided to increase their income to fulfil family's needs through working abroad.

\section{References}

Appleyard, R.T. 1982. Methods of Estimating and Analysing International Migration. Dalam United Nations. Economic And Social Commission For Asia And The Pacific. National migration surveys X. Guidelines for analyses, New York.

Boyd, M.1989. Family and Personal Networks in International Mints and New Migration: Recent Developments and New Agendas. Internasional Migration Review (3): 638-670.

Castles, S and Mark J. Miller. 1993. The Age Of Migration: Inter-Nasional Population Movements In The Modern World.London: Mac Millan.

De Jong, G.F and J.T. Fawcett. 1981. Motivation For Migration: An Assessment And A Value Expectancy Reseach Model . Pergamon Press.

Fawcett, J.T. 1989. Networks Linkages and Migration System. Internasional Migration System'internasional Migration Review 23: (3): 671-680.

Goma, J.N.1993. Mobilitas Tenaga Kerja Flores Timur ke Sabah Malaysia dan Pengaruhnya Terhadap Daerah Asal. Studi Pasca Desa Neleren, Kecamatan Adonara, Kabupaten Flores Timur. Yogyakarta: Universitas Gadjah Mada.Tesis Program Studi Pasca Sajarna. Universitas Gadjah Mada. 
Hugo, G.J. 1991. Migrant Women in Developing Countries, Paper Presented at The United Nations Expert Keban Group Meeting on The Feminisation of Internal Migration. Aquascalientes. Mexico.

Hermon, D., Khairani., Daswirman., S. Karim., Dasrizal., and Triyatno. 2008. Metode dan Teknik Penelitian Geografi Tanah: Aplikasi Instrumen dan Acuan Penelitian Geografi Fisik. Yayasan Jihadul Khair Center.

Hermon, D. 2009. Dinamika Permukiman dan Arahan Kebijakan Pengembangan Permukiman pada Kawasan Rawan Longsor di Kota Padang. Disertasi. IPB Bogor.

Hermon, D. 2010. Arahan Kebijakan Pengembangan Permukiman pada Kawasan Rawan Longsor di Kota Padang. Jurnal SKALA. Vol. 1.

Hermon, D. 2012. Mitigasi Bencana Hidrometeorlogi: Banjir, Longsor, Degradasi Lahan, Ekologi, Kekeringan, dan Puting Beliung. UNP Press. Padang.

Hermon, D. 2014. Desain Kebijakan Tanggap Darurat dan Pemulihan Bencana Letusan Gunung Sinabung. Seminar Nasional Geografi. Master Program of Geography Education, Universitas Negeri Padang.

Hermon, D. 2015. Geografi Bencana Alam. Jakarta: PT RajaGrafindo Persada.

Hermon, D. 2016. Mitigasi Perubahan Iklim. Rajawali Pers (Radjagrafindo).

Hermon, D. 2017. Climate Change Mitigation. Rajawali Pers (Radjagrafindo).

Hermon, D., Y. Suasti., Ernawati., Afdhal., and H. Edial. 2018. Geografi: Geografi untuk SMU. Jurusan Geografi Universitas Negeri Padang.

Keban, Y.T. 1995. Migrasi Internasional: Kecendrungan Determinan, Dampak dan Kebijakan. Paper Pelatihan Mobilitas Penduduk. Yogyakarta. 11-23 Desember.

Lewis, J.R. 1986. Internasional Labour Migration And Uneven Regional Development In Labour Exporting Countries. TESG (Tijdschrift Voor Econ.En Soc.Geografie). 77 (1): 27-41.

Mantra, I.B.1989. Mobilitas Penduduk Sirkuler dari Desa Ke Kota Di Indonesia.Yogyakarta. Pusat Penelitian Kependudukan Universitas Gadjah Mada.

Hugo, G.J. 1993. Indonesia Labour Migration to Malaysia: Trends and Policy Implication. South Asian Jurnal of Social Science. Vol. 21 No 1.

Kitz, M.M and H. Zlonik. 1992. Global Interactions, Migration Systems, Processes and Policies. Clarendon Press. 